\title{
Aqueous humour and serum zinc and copper concentrations of patients with glaucoma and cataract
}

\author{
Nurettin Akyol, Orhan Deǧer, E Edip Keha, Saim Kiliç
}

\begin{abstract}
Serum and aqueous humour zinc and copper concentrations of 44 patients with glaucoma and cataract were determined. Serum values were found within normal ranges. The highest mean copper concentration was seen in the glaucoma group. In addition there was a significant negative correlation between the aqueous humour levels of zinc and copper in patients with glaucoma. It was concluded that an increased copper value together with a low zinc value might be of importance in patients with glaucoma.
\end{abstract}

Zinc and copper are essential trace elements and are present in ocular tissues. ${ }^{1}$ That zinc and copper are needed for the growth and well-being of both plants and animals is well established. The metabolic functions of these elements are largely based on their presence in metalloenzymes. ${ }^{2}$ Trace element investigations in the aqueous humour have been carried out in animals. ${ }^{3+}$

In this study we aimed to determine the aqueous humour zinc and copper levels of patients with cataract and glaucoma and to look for any correlation between these values.

\section{Materials and methods}

Faculty of Medicine, Karadeniz Technical University, Trabzon, Turkey

Department of

Ophthalmology

N Akyol

S Kiliç

Department of

Biochemisty

O Değer

E E Keha

Correspondence to:

Nurettin Akyol, Assistant Professor, Department of Ophthalmology Faculty of Medicine, Karadeniz

Technical University, 61080

Trabzon, Turkey.

Accepted for publication

17 May 1990
The study included 44 patients - 20 with senile cataract, 10 with glaucoma, 8 with glaucoma + cataract, and 6 with congenital cataract.

Sterile disposable syringes and hypodermic needles were used to collect blood and aqueous humour samples. The aqueous humour sample was taken during the operation after incision of the conjunctiva and just before opening the anterior chamber. Blood was centrifuged to obtain serum. All samples were immediately stored at $-20^{\circ} \mathrm{C}$ until analysed. All measurements were made with the GBC Scientific Equipment atomic absorption spectrophotometer (Model 902), with copper and zinc hollow cathode lamps at 0.5 slit width and graphite furnace.

The results were analysed by Kruskal-Wallis

Table 1 Zinc and copper concentrations (arithmetic mean and standard error of mean)

\begin{tabular}{|c|c|c|c|c|c|}
\hline \multirow[b]{2}{*}{ Group } & \multirow[b]{2}{*}{$n$} & \multicolumn{2}{|c|}{ Zinc, mean $(S E M)(\mu g / m l)$} & \multicolumn{2}{|c|}{ Copper, mean $(S E M)(\mu g / m l)$} \\
\hline & & Aqueous humour & Serum & Aqueous humour & Serum \\
\hline $\begin{array}{l}\text { I. Senile cataract } \\
\text { II. Glaucoma } \\
\text { III. Glaucoma + cataract } \\
\text { IV. Congenital cataract }\end{array}$ & $\begin{array}{r}20 \\
10 \\
8 \\
6\end{array}$ & $\begin{array}{l}0.144(0.010) \\
0.154(0.020) \\
0.122(0.018) \\
0.178(0.042)\end{array}$ & $\begin{array}{l}1.37(0.071) \\
1.26(0.126) \\
1.42(0.099) \\
1.22(0.098)\end{array}$ & $\begin{array}{l}0.047(0.006) \\
0.112(0.024)^{\star} \\
0.068(0.015) \\
0.070(0.028)\end{array}$ & $\begin{array}{l}1.85(0 \cdot 154) \\
1.94(0 \cdot 183) \\
1 \cdot 78(0 \cdot 247) \\
1.80(0 \cdot 289)\end{array}$ \\
\hline
\end{tabular}

^Significantly different from group I at $\mathbf{p}<0.05$.

SI conversion: Zinc $\mu \mathrm{g} / \mathrm{ml} \times 15 \cdot 3=\mu \mathrm{mol} / \mathrm{l}$. Copper $\mu \mathrm{g} / \mathrm{ml} \times 15 \cdot 7=\mu \mathrm{mol} / \mathrm{l}$

variance analysis, unpaired $t$ test, and correlation analysis.

\section{Results}

The results obtained for human aqueous humour zinc and copper concentrations are given in Table 1. Distribution diagrams are given in Figures 1 and 2.

The mean serum zinc concentrations in all groups were within the normal range of our laboratory $(0 \cdot 8-1 \cdot 4 \mu \mathrm{g} / \mathrm{ml}(12 \cdot 2-21 \cdot 4 \mu \mathrm{mol} / \mathrm{l}))$, whereas copper concentrations were slightly higher $(0 \cdot 9-1 \cdot 60 \mu \mathrm{g} / \mathrm{ml}(14-25 \mu \mathrm{mol} / \mathrm{l}))$. But no significant difference was found among the groups for both zinc and copper. The highest mean aqueous humour copper concentration was found in the group of glaucoma patients. By analysis of variance a significant difference was found among the groups $(p<0.05)$ for aqueous humour copper concentrations, but not for zinc. The difference was observed only between the mean aqueous humour concentrations of patients with glaucoma or senile cataract. In addition, correlations were established for aqueous humour, but not serum, between zinc and copper (in the group of glaucoma patients $r=-0.755, p<0.01$ and in the group of patients with glaucoma + cataract $\mathrm{r}=-0.806, \mathrm{p}<0.01$ ) (Fig 3).

\section{Discussion}

We could not find any reports on the trace element concentrations in aqueous humour of patients with cataract and glaucoma. Gerhard et $a l^{5}$ found the zinc concentrations as 0.27 $0.44 \mu \mathrm{g} / \mathrm{ml}(4 \cdot 1-6 \cdot 7 \mu \mathrm{mol} / \mathrm{l})$. Moster $e^{2} a^{6}$ found

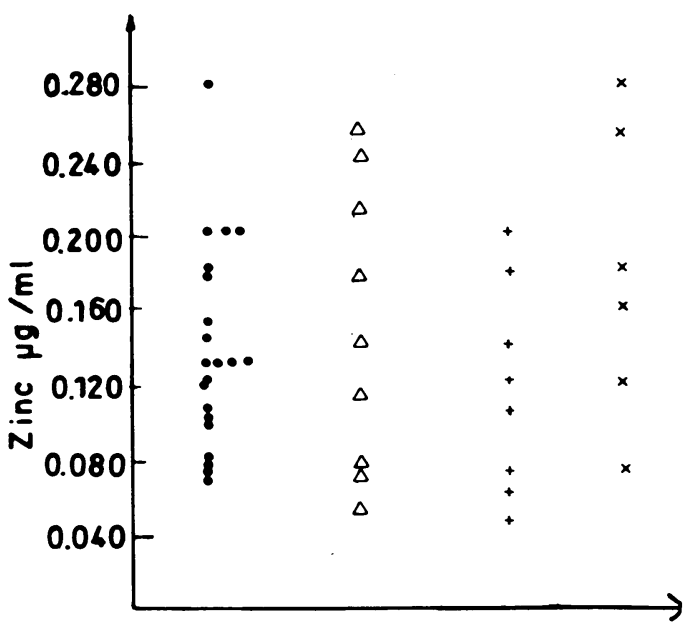

Figure 1 Distribution diagram for aqueous humour zinc concentrations (O: senile cataract

$\triangle$ : glaucoma, $+:$ glaucoma + cataract, $\times$ : congenital cataract). $S I$ conversion: $\mu \mathrm{g} / \mathrm{ml} \times 15 \cdot 3=\mu \mathrm{mol} / \mathrm{l}$. 


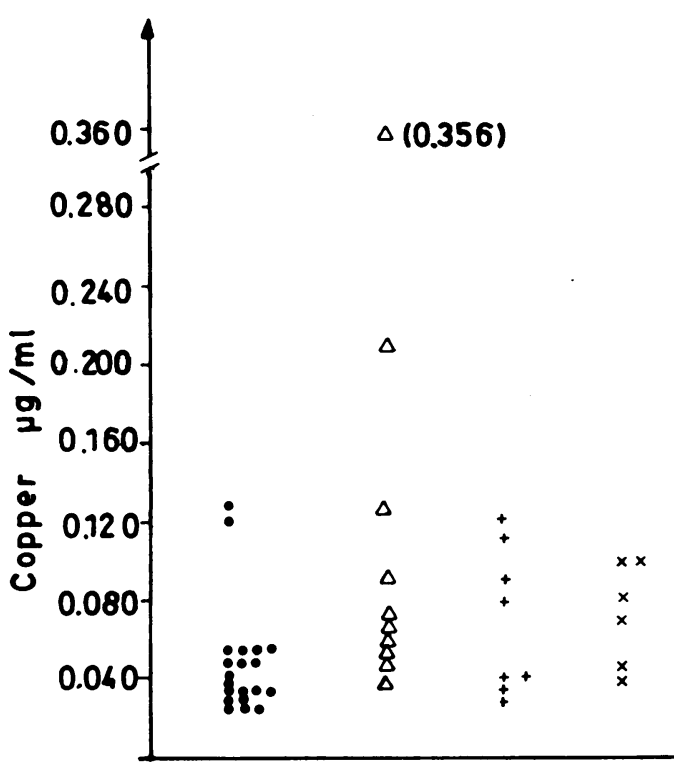

Figure 2 Distribution diagram for aqueous humour copper concentrations (legends as for Figure I). SI conversion: $\mu g / m l \times 15 \cdot 7=\mu m o l l l$.

the copper concentration to be $0.018-0.080 \mu \mathrm{g} / \mathrm{ml}$ $(0 \cdot 28-1 \cdot 3 \mu \mathrm{mol} / \mathrm{l})$ in the aqueous humour of normal human subjects. In the present study, for the patients with cataract and glaucoma, we observed higher copper and lower zinc concentrations than the values noted above. In general, copper and zinc are reported to be metabolical antagonists. ${ }^{27}$ This supports the negative correlation which we have found between the copper and zinc concentrations in the aqueous humour of the patients with glaucoma. A high copper level together with a low zinc level may be caused by the following factors: (1) abnormalities in the secretion of aqueous humour $;$; (2) difficulties in the outflow of aqueous humour through canal of Schlemm ${ }^{8}$; and (3) breakdown of the blood-aqueous humour barrier as a result of trauma, infection, and inflammation.' In normal circumstances it was found that the blood-ocular barrier effectively excludes a potentially toxic excess copper from the eye. ${ }^{4}$ Breakdown of the barrier has been shown to result in increase of copper levels in aqueous humour, which is associated with an influx of plasma proteins into the anterior chamber. ${ }^{410}$ Thus in one of our patients who had a glaucomatocyclitic crisis (Posner-Schlossman syndrome) we found an aqueous humour zinc concentration of 0.050 $\mu \mathrm{g} / \mathrm{ml}(0.76 \mu \mathrm{mol} / \mathrm{l})$ and copper concentration of $0.356 \mu \mathrm{g} / \mathrm{ml}(5.6 \mu \mathrm{mol} / \mathrm{l})$. It has been reported that during the stress of infection or inflamma-

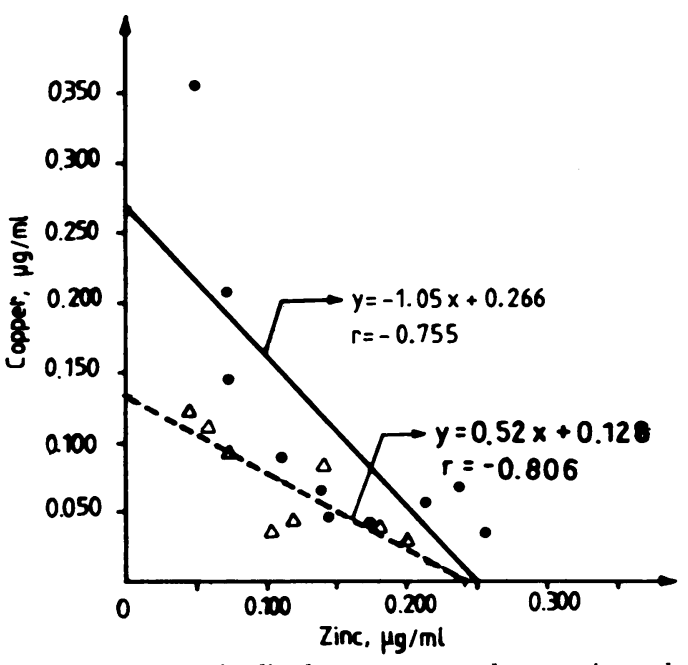

Figure 3 Regression line between aqueous humour zinc and copper concentrations (O: glaucoma, $\triangle$ : glaucoma + cataract).

tion copper levels rise and zinc levels fall owing to the acute-phase reaction. ${ }^{2}$ Moreover there may be slightly increased serum copper levels in all groups for the reasons noted above.

According to our results here a negative correlation between aqueous humour copper and zinc levels in patients with glaucoma, especially when caused by trauma and inflammation, may be of importance. It is concluded that increase in the copper concentration in the aqueous humour may indicate a breakdown of the blood-aqueous barrier. This subject needs further investigation.

1 Eckhert CD. Elemental concentrations in ocular tissues of various species. $\operatorname{Exp} E$ Eye Res 1983; 37: 639-47.

2 Jacob RA. Trace elements. In: Tietz NW, ed. Fundamentals of clinical chemistry. Philadelphia: Saunders, 1987: 517-32.

3 McGahan MC, Bito LZ. Determination of copper concentration in blood plasma and in ocular and cerebrospinal fluids using graphite furnace atomic absorption spectroscopy. Anal Biochem 1983; 135: 186-92.

4 Cook CS, Grubb B. Experimental hypercupremia does not result in increases in copper in levels, iris or ocular fluids. Curr Eye Res 1986; 5: 171-3.

5 Gerhard JP, Calmé P, Kraeminger E. A propos du zinc de l'humeur aqueuse. Klin Monatsbl Augenheilkd 1980; 176: $652-4$.

6 Moster MF, Riebel O, Komárek J. Determination of copper and iron in aqueous by means of atomic absorption spectrometry. Cesk Oftalmol 1980; 36: 190-4.

7 Oestreicher P, Cousins RJ. Copper and zinc absorption in the rat: mechanism of mutual antagonism. $\mathcal{F}$ Nutr 1985; 115: rat: mecha

8 Hoskins HD, Koss M. Becker-Shaeffer's diagnosis and therapy of the glaucomas. St Louis: Mosby, 1989: 41-66.

9 Caprioli J. The ciliary epithelia and aqueous humour. In Moses RA, Hart WM, eds. Adler's physiology of the eye. Clinical Application. St Louis: Mosby, 1987: 204-22.

10 McGahan MC, Bito LZ. The pathophysiology of the ocular microenvironment. I. Preliminary report on the possible involvement of copper in ocular inflammation. Curr Eye Res 1983; 2: 883-5. 